PRZEGLĄD NAUK HISTORYCZNYCH 2018, R. XVII, NR 2

http://dx.doi.org/10.18778/1644-857X.17.02.07

\title{
„Jedna z najdonioślejszych epok w życiu Żydów" Kongres Żydów Amerykańskich w Filadelfii (15-18 grudnia 1918 roku)
}

Streszczenie. Kongres Żydów Amerykańskich jako organizacja mająca na celu reprezentowanie wszystkich Żydów zamieszkujących Stany Zjednoczone zapoczątkował swoją działalność od zjazdu w Filadelfii. W dniach 15-18 grudnia 1918 r. doszło do spotkania 400 delegatów reprezentujących wszystkie żydowskie stronnictwa polityczne i grupy społeczne w USA. Budził on ogromne nadzieje, ponieważ przed Żydami otwierały się nowe możliwości co do rozwiązania kwestii palestyńskiej, głównego projektu syjonistów, a także zagwarantowania równych praw mniejszościom żydowskim w Europie Środkowo-Wschodniej. W artykule została udzielona odpowiedź na pytania o to, jak doszło do zwołania Kongresu Żydów Amerykańskich. Jak ustosunkowały się do niego główne ugrupowania polityczne Żydów w USA? Co było przedmiotem obrad? Jakie decyzje podjęto? A następnie w jaki sposób je zrealizowano i jakie były dalsze losy inicjatywy zapoczątkowanej w Filadelfii? Odpowiedzi na powyższe kwestie pozwola sformułować wniosek co do tego, jaka wage miał grudniowy kongres w dziejach Żydów w USA oraz czy wypełnił stawiane przed nim zadania.

Słowa kluczowe: Żydzi w USA, Kongres Żydów Amerykańskich, kwestia palestyńska, syjonizm, prawa mniejszości.

W

grudniu 1918 r. odbył się pierwszy w historii kongres przedstawicieli Żydów mieszkających w Stanach Zjednoczonych. Przez niektórych spotkanie 400 delegatów wybranych przez ponad 320 tys. elektorów jest nazywane „zapo-

* Wydział Filozoficzno-Historyczny, Instytut Historii, Katedra Historii Powszechnej Najnowszej, e-mail: dariuszjeziorny@uni.lodz.pl. 
mnianym kongresem" ${ }^{1}$. Jednakże w momencie jego otwarcia jeden $z$ mówców zaliczył to, co działo się w Filadelfii, do „jednych $z$ najdonioślejszych epok w życiu Żydów”, ponieważ „pierwszy raz Żydzi wszystkich klas, wszystkich grup i wszystkich stronnictw, na które podzielone jest amerykańskie żydostwo, zebrali się razem, ażeby uroczyście i z ogromnymi nadziejami obradować"2. Rzeczywiście po raz pierwszy w historii żydowskiej diaspory w USA, liczacej wówczas ok. 3,3 mln osób i osiedlonej głównie w wielkich amerykańskich miastach ${ }^{3}$, doszło do spotkania mogącego sobie rościć aspiracje do reprezentowania całej społeczności. Nic dziwnego, że pisały o tym wszystkie najważniejsze gazety amerykańskie o zasięgu ogólnokrajowym ${ }^{4}$.

Zauważyć należy, że w tym samym okresie odbywały się podobne zjazdy przedstawicieli mniejszości żydowskich: w Budapeszcie dla mieszkańców Węgier, w Wiedniu dla Austrii, w Krakowie dla Galicji Zachodniej, we Lwowie dla Galicji Wschodniej zdobytej przez Polaków, w Stanisławowie dla Galicji Wschodniej opanowanej przez wojska Zachodnioukraińskiej Republiki Ludowej, w Warszawie dla Królestwa Polskiego, w Zagrzebiu dla Chorwacji, w Czerniowcach dla Bukowiny i w Pradze dla $\mathrm{Czech}^{5}$. Żaden $z$ wymienionych zjazdów nie zdobył jednakże porównywalnego rozgłosu. Niewątpliwie obecni na nich byli Żydzi wszystkich opcji politycznych danego

${ }^{1}$ J. Loeffler, Nationalism without a Nation? On the Invisibility of American Jewish Politics, „The Jewish Quarterly Review” 2015, vol. CV, No. 3, s. 368.

2 Jews Ask Voice at Peace Table. Congress in Philadelphia to Take Up Palestine and Other Questions, „Washington Post” [dalej: WP], 16 XII 1918, s. 5; American Jews Ask Full Rights in All States. Judge Mack, Chicago, Named President of Congress, "Chicago Daily Tribune” [dalej: ChDT], 16 XII 1918, s. 15; Jewish Congress Voices Its Hopes, „Boston Globe” [dalej: BG], 16 XII 1918, s. 6.

${ }^{3}$ Metropolie amerykańskie $\mathrm{z}$ największym odsetkiem ludności żydowskiej pod koniec 1918 r. to Nowy Jork (ponad 1,5 mln osób), Chicago (225 tys.), Filadelfia (200 tys.), Cleveland (100 tys.), Boston (77,5 tys.), Baltimore, St. Louis, Pittsburg (po 60 tys.), Newark (55 tys.), Detroit (50 tys.). Więcej na ten temat por. G. Cohen, Jews in the Making of America, Boston 1924, s. 362, 364.

${ }^{4} \mathrm{~W}$ artykule przedstawione zostana wyniki kwerendy w piecciu tytułach prasowych, ale za to najbardziej opiniotwórczych w ówczesnych Stanach Zjednoczonych „New York Times” [dalej: NYT], „Washington Post”, „Boston Globe”, „Chicago Daily Tribune” i „Los Angeles Times” [dalej: LAT]. Kwerenda objęła również „Wall Street Journal”, w którym jednakże tematyka polityczna była praktycznie marginalna i o Kongresie Żydów Amerykańskich nie pojawiła się ani jedna wzmianka.

${ }^{5}$ D. Jeziorny, Londyn wobec ochrony mniejszości żydowskich $w$ Europie Środkowo-Wschodniej (1918-1919), Łódź 2016, s. 55-56; W. J a w or ski, Syjoniści wobec rzadu polskiego w okresie międzywojennym, Sosnowiec 2002, s. 9-12. 
regionu. Mimo to wpływ tych ludzi na losy diaspory żydowskiej w skali globu był nieporównanie mniejszy niż możliwości działania Żydów zamieszkałych w Stanach Zjednoczonych. Dlatego też warto odpowiedzieć na pytania, jak doszło do zwołania w Filadelfii tak znaczacego kongresu. W drugiej kolejności trzeba zastanowić się nad kwestią tego, czy grudniowe spotkanie spełniło tak wielkie pokładane w nim nadzieje, czyli co zostało uchwalone oraz jak realizowano podjęte decyzje. Na koniec nie bez znaczenia będzie odpowiedź na pytanie o dalsze losy inicjatywy, która, jak wspomniano, nosi nazwę „zapomnianego kongresu”.

Droga do pierwszego ogólnoamerykańskiego spotkania Żydów nie była łatwa. Dyskusja w tej sprawie trwała przez praktycznie cała I wojnę światowa. Promotorem kongresu byli przede wszystkim syjoniści, czyli opcja dążąca do realizacji idei państwa żydowskiego, najlepiej w Palestynie. Federacja Amerykańskich Syjonistów (Federation of American Zionists, dalej: FAZ) odniosła w USA ogromny sukces organizacyjny. $Z$ niespełna 12 tys. członków w 1914 r. cztery lata później było ich już 176 tys. Złożyło się na to kilka powodów, spośród których, obok deklaracji lorda Balfoura z 2 listopada 1917 r. i wkroczenia wojsk brytyjskich do Jerozolimy w następnym miesiącu, najważniejsze było zaangażowanie na rzecz syjonizmu Louisa D. Brandeisa. Był sędzią Sąu Najwyższego USA, bliskim współpracownikiem prezydenta Thomasa W. Wilsona, człowiekiem popularnym w świecie robotników, którym udzielał swojej pomocy prawnej w trakcie ich walki o polepszenie warunków pracy i płacy. Było wśród nich wielu żydowskich imigrantów $z$ Rosji i innych krajów Europy Środkowo-Wschodniej, gdzie tęsknota za Palestyna była naprawdę ogromna ze względu na ich traktowanie przez władze państw pochodzenia. Tym sposobem Brandeis, stojąc u szczytu kariery zawodowej, zdobył popularność Żydów ze wszystkich grup społecznych obecnych w USA. Miał bliskie kontakty zarówno $z$ bogatymi współwyznawcami pochodzenia niemieckiego o ustabilizowanym statusie materialnym, $z$ przedstawicielami klasy średniej, jak i z najliczniejszą grupa niewykwalifikowanych robotników, napływajacych do Ameryki w latach 1881-1914 (ok. 2 mln osób). Reprezentować ją chcieli syjoniści oraz socjaliści rozmaitych odcieni. To zaś wynosiło go, jako znakomitego mówcę i „prawnika ludowego", na coraz wyższe stopnie kariery politycznej ${ }^{6}$.

${ }^{6}$ N. Glazer, The Jews, [w:] Ethnic Leadership in America, ed. J. Higham, Baltimore-London 1979, s. 25-26; L. Pas tu siak, Prezydenci, wyd. 2, t. II, Warszawa 
Jako że sytuacja Żydów na terenie Europy Środkowo-Wschodniej się pogarszała, FAZ od 1915 r. zaczęła proponować liderom pozostałych organizacji zrzeszających Żydów amerykańskich wspólna płaszczyznę działania. Głównym powodem współpracy miało być polepszenie doli współwyznawców w Europie Wschodniej, gdzie już przed wojna sytuacja Żydów była, najkrócej mówiąc, bardzo trudna 7 . Głównymi partnerami syjonistów do rozmów byli Amerykański Komitet Żydowski (American Jewish Committee, dalej: AJC) oraz różne organizacje robotnicze. Podziały wśród nich zostały przeniesione $z$ terenów Rosji i Austro-Węgier, skąd głównie przybywali imigranci. Środowiska socjalistyczne znakomicie zdawały sobie sprawę, że syjoniści to ich główni konkurenci w walce o "rząd dusz" wśród robotników. Ze swej strony powołali w sierpniu 1915 r. Robotniczy Komitet na Rzecz Praw Żydowskich, który domagał się całkowitej równości politycznej, obywatelskiej i narodowo-kulturalnej. Początkowo nie zauważyli zagrożenia ze strony FAZ, dążacej do wchłonięcia mniejszych ugrupowań politycznych. Jednakże $z$ czasem wycofali się ze współpracy $z$ powodu chęci dopuszczenia przez syjonistów do obrad jedynie delegatów, którzy mogli się wylegitymować obywatelstwem amerykańskim. A że aktywistami socjalistycznymi byli częstokroć świeżo przybyli do USA działacze robotniczy z Rosji, obóz antysyjonistyczny zyskał argument do odrzucenia syjonistycznej oferty współpracy ${ }^{8}$.

Dość zaskakująco więc głównym sojusznikiem w sprzeciwianiu się propozycji FAZ co do zwołania Kongresu Żydów Amerykańskich był Amerykański Komitet Żydowski. Organizację tę, istniejąca od 1906 r., można nazwać „elitarnym klubem”, czyli w stosunku do

1989, s. 328; J. Daniels, The Wilson Era. Years of War and After, New York 1946, s. 216-217; G. Cohen, op. cit., s. 212-213; A.T. Mas on, Brandeis. A Free Man's Life, New York 1946, s. 442-444, 451; Racial and Cultural Minorities. Analysis of Prejudice and Discrimination, rev. eds G.E. Simpson, J.M. Yinger, New York 1958, s. 314-316; L. Baker, Brandeis and Frankfurter. A Dual Biography, New York 1984, s. 73-75, 161-162.

7 Istnieje $\mathrm{w}$ tej sprawie ogromna literatura przedmiotu, np. A. Polonsky, Dzieje Żydów w Polsce i Rosji, Warszawa 2014, s. 73-218; L. Poliakov, Historia antysemityzmu, t. II, Kraków 2008, s. 279-297; Pogroms: Anti-Jewish Violence in Modern Russian History, eds J.D. Klier, S. Lambroza, Cambridge 1992; J. Parkes, The Emergence of the Jewish Problem. 1879-1939, London-New YorkToronto 1946, s. 91-103.

${ }_{8}$ M. E pstein, Jewish Labour in USA. An Industrial, Political and Cultural History of Jewish Labour Movement. 1914-1952, vol. II, New York 1969, s. 62. 
socjalistów były to antypody sceny politycznej. Przewodził jej znany nowojorski prawnik, Louis Marshall. Zrzeszała bardzo wpływowe osoby amerykańskiego życia gospodarczego, finansowego, społecznego i politycznego ${ }^{9}$. Byli to głównie emigranci $z$ Niemiec lub ich potomkowie w pierwszej generacji, którzy odnieśli ogromny sukces $\mathrm{w}$ prowadzonych przez siebie interesach, nierzadko we wspólpracy $z$ członkami rodziny pozostałymi na Starym Kontynencie ${ }^{10}$. Zawężenie liczebne AJC (członkostwo na zasadzie kooptacji - decydowały „prestiż i mądrość” kandydatów) nie przeszkadzało organizacji pozostawać bardzo wpływowa i to nie tylko w skali kraju, lecz także szerzej. Swoja siłę działania Komitet upatrywał w instrumentach politycznych (rozmowy „wpływowych z wpływowymi”) lub zachętach ekonomicznych (udzielanie pomocy finansowej i gospodarczej albo jej wstrzymywanie). Jako że kongres proponowany przez syjonistów miał się opierać na jedynie słusznych w ówczesnej rzeczywistości amerykańskiej zasadach demokracji, gdzie większość musiała przypaść siła rzeczy syjonistom, Amerykański Komitet Żydowski wstrzymywał się przed współdziałaniem, nie chcąc utracić posiadanych wpływów ${ }^{11}$. Z Komitetem współpracowała wprawdzie bardziej liczebna (w 1918 r. kilka tysięcy człon-

9 Warto w tym kontekście przytoczyć choćby kilka najważniejszych nazwisk: Oscar Straus (najbardziej znacząca postać życia żydowskiego w USA w pierwszych latach XX w., zasiadająca w Międzynarodowym Trybunale Arbitrażowym w Hadze, były przewodniczacy AJC, zwany „dziekanem” bankierów żydowskich w Nowym Jorku, sekretarz ds. handlu i pracy w administracji Theodora Roosevelta), Julius Rosenwald (chicagowski „książę kupców amerykańskich”, głowa domu SearsRoebuch, członek Komisji Doradczej Rady Obrony Narodowej w administracji Wilsona i to mimo przynależności do Partii Republikańskiej), Jacob H. Schiff (szef największego amerykańskiego banku inwestycyjnego Kuhn, Loeb \& Co., znany ze swej działalności filantropijnej).

${ }_{10}$ Za przykład niech służa postacie braci Paula i Felixa Warburgów (pierwszy to jeden ze współtwórców Systemu Rezerwy Federalnej, związany z domem Kuhn, Loeb \& Co, a drugi to przewodniczacy Joint Distribution Committee, rozsyłajacego pomoc Żydom Europy Środkowo-Wschodniej). Ich brat Max Warburg był jednym z głównych bankierów niemieckich, a po I wojnie światowej znalazł się w delegacji, która pojechała do Paryża odebrać pierwszą wersję warunków pokojowych, ustalonych przez mocarstwa Ententy.

${ }^{11}$ G.D. Best, To Free a People. American Jewish Leaders and the Jewish Problem in Eastern Europe 1890-1914, Westpork 1982, s. 196, 206, 209-211; A.A. Goren, New York Jews and the Quest for Community. The Kehillah Experiment 1908-1922, New York-London 1970, s. 16, 22, 26, 30; N. Glaze r, op. cit., s. 22-23; G. Cohen, op. cit., s. 106, 108-109, 217-218, 222-224, 226-228; J. Danie1s, op. cit., s. 216, 218; M. Epstein, op. cit., s. 58. 
ków) loża wolnomularska Niezależny Zakon B'nai B'rith (Synowie Przymierza) ${ }^{12}$, najstarsza organizacja żydowska w USA (aktywna od 1843 r.). Sposobem działania nie odbiegała ona jednak zbytnio od modelu AJC. Chodziło o lobbowanie na rzecz polepszenia doli Żydów w różnych częściach świata u najważniejszych polityków USA. W 1913 r. utworzono dodatkowo Anti-Defamation League of B'nai B'rith, jako stowarzyszenie zwalczajace wszelkie przejawy antysemityzmu. Pozwalało ono prowadzić bardziej energiczna działalność uświadamiającą wśród opinii publicznej ${ }^{13}$.

Za sporem między Federacja Amerykańskich Syjonistów a pozostałymi środowiskami politycznymi Żydów w USA stała jednakże nie tylko taktyka walki o pozycję polityczna. Sprawa miała bardziej pryncypialny wydźwięk. Antysyjoniści w szeregach Żydów amerykańskich byli zwykle osobami o ugruntowanej pozycji, gdy chodzi o dochody i o stanowiska. Chcieli, aby Amerykanie myśleli o nich jak o części swojej elity i aby byli postrzegani jako obywatele lojalni wobec swojej ojczyzny, Stanów Zjednoczonych. To właśnie USA i każdy inny kraj osiedlenia Żydów należało postrzegać, zdaniem antysyjonistów, jako współczesny Syjon, na którym można by rozwijać wszystkie niezbędne aspekty życia. Opowiadanie się za powstaniem państwa żydowskiego w Palestynie siłą rzeczy musiało owocować pytaniem, który kraj tak naprawdę liczył się dla Żydów bardziej: USA czy Izrael; lub który hymn chce ktoś śpiewać jako swój własny - amerykański Star-spangled Banner czy syjonistyczna Hatikvah; a wreszcie którą flage uznaje się za swoją - „Star and Stripes" czy sześcioramienna niebieska gwiazdę na białym tle. Sfera symboliczna była w tym wypadku bardzo podkreślana, stąd odcinanie się od wszelkich przejawów nacjonalizmu żydowskiego i podkreślanie w tych środowiskach wierności wobec kraju zamieszkania. Składała się na nią także odwaga żołnierzy pochodzenia żydowskiego, walczacych na frontach I wojny światowej i ginacych w interesie racji stanu Waszyngtonu. Podejrzenia o podwójna lojalność prowadziły, zdaniem przeciwników syjonizmu, do antysemityzmu, który mógł całkowicie podkopać położenie Żydów w Stanach Zjednoczonych. Mogli się oni zetknąć z zarzutem bogacenia się na

${ }_{12}$ Początkowo Simon Wolf i Adolf Krause, stojacy na czele B'nai B'rith w latach 1905-1928, należeli do AJC, ale w 1907 r. wystąpili z jego szeregów. Por. G.D. Best, op. cit., s. 131-133.

13 https://pl.wikipedia.org/wiki/B'nai_B'rith; M. Sklare, The Jewish Community in America, New York 1974, s. 80-81; N. Glazer, op. cit., s. 26; A.A. Gore n, op. cit., s. 22; G.D. Best, op. cit., s. 14-16, 212-213, 220. 
Amerykanach w trakcie swego „czasowego pobytu” w USA, ażeby $z$ zarobionymi pieniędzmi wyjechać następnie do Palestyny. Ze strony amerykańskich antysemitów spodziewano się presji i nakłaniania Żydów - jako „niepożądanych obcych” - do wyjazdu do „ich własnego kraju". Takich jednakże, którzy chcieliby opuścić Stany Zjednoczone, było niewielu. Dawało to kolejny argument przeciwko syjonistom, przedstawianym jako zdecydowana mniejszość diaspory w USA. Niechęć do Żydów mogła też zmaterializować się przez wytknięcie zakulisowych działań w celu wpłynięcia na poszczególnych polityków czy wręcz całe rządy - wszak pieniądze dawały taka możliwość. W tym wypadku Żydzi zdawali sobie sprawę, co mogłoby razić opinię publiczną. Ponadto przeciwnicy syjonizmu twierdzili, że słowo „Żyd” oznaczało człowieka wyznającego judaizm, a nie osobę narodowości żydowskiej. Narodowość, do której się przyznawali, to „Amerykanin” i to w 100\%. Ponadto „Żydowska Palestyna”, nazywana nieraz „tak zwaną ojczyzną, kojarzyła się antysyjonistom $z$ zagrożeniem połączenia państwa i religii, co byłoby krokiem wstecz „o tysiące lat” wobec zdobyczy liberalnego systemu rządów. $Z$ tym zresztą ortodoksyjni rabini popierający syjonizm specjalnie się nie kryli. Bazowali na biblijnych proroctwach, zwiastujących powrót Żydów na Syjon. Głosili, że zaprowadzą w swoim państwie porządki w systemie politycznym i ekonomicznym oparte na nauczaniu $z$ religii mojżeszowej. Kolejnym zarzutem przeciwników syjonizmu była utopijność rozwiąania, które nie dawało możliwości pomocy Żydom żyjącym w opresji na rozwój kulturowy lub edukacyjny. Palestyna była bowiem terenem zbyt ograniczonym i biednym, aby przyjać cierpiących współwyznawców ze wschodniej części Europy.

Oprócz argumentacji stricte polityczno-ekonomicznej pojawiała się inna. Przeciwnicy syjonizmu rekrutowali się z szeregów Żydów religijnych, gdzie zreszta istniały głębokie podziały. Przeciw idei kongresu, kojarzonego $z$ syjonistami, występowali zwolennicy judaizmu reformowanego ${ }^{14}$. Powoływali się na uchwały konferencji rabinów z 1869 i 1889 r., gdy odżegnywano się od „nacjonalizmu palestyńskiego" w judaizmie w USA. Wycofano nawet stare

${ }^{14}$ Więcej o zasadach przyjętych przez reformatorów w połowie XIX w. w: A. U nterman, Żydzi. Wiara i życie, Łódź 1989, s. 97-101. Na gruncie amerykańskim prekursorem judaizmu reformowanego był Isaac Mayer Wise, który utworzył pierwsze reformowane seminarium rabiniczne w USA w Cincinatti - por. A. Hertzberg, A. Hirt-Man heimer, Żydzi. Istota i charakter narodu, Warszawa 2001, s. $178-180$. 
modlitwy o odbudowanie Palestyny. Takie decyzje dały poczatek rozwoju Union of American Hebrew Congregations, który skupiał w 1918 r. ponad 200 kongregacji judaizmu reformowanego. Właściwie większość Żydów amerykańskich sprzed 1881 r. czuła się związana $z$ tą właśnie odmianą religii mojżeszowej. Nadawano jej zresztą charakter misyjny, stąd przyjęcie języka angielskiego jako języka liturgii, ażeby modlitwa, Biblia i jej wykład były zrozumiałe dla osób pochodzacych spoza świata żydowskiego. W tym znaczeniu „odbudowa oddzielnej narodowości wśród Żydów to zagrożenie dla judaizmu", gdyż ograniczyłaby możliwość wyznawania religii mojżeszowej jedynie do osób urodzonych $z$ matki-Żydówki. W ostatnich latach przedwojennych powyższe założenia uległy zdecydowanemu zachwianiu, ponieważ z Europy Wschodniej napłynęło do USA wielu Żydów ortodoksyjnych, którzy w ogóle nie zamierzali zasymilować się ze środowiskiem nowej ojczyzny i pozostali przy języku hebrajskim jako języku modlitw. Co istotne, tym napływającym do Stanów Zjednoczonych Żydom nie przeszkadzał program syjonistów. Stwierdzali oni wręcz, że czują się częścią rasy i narodowości żydowskiej, stąd formułowano zarzut wobec syjonistów, że nie robia nic, aby uczynić $z$ napływających migrantów Amerykanów, którzy by się dostosowali do warunków panujacych w USA i mieli $z$ tym krajem łączność. Przeciwnicy syjonizmu twierdzili wręcz, że gdyby taka postawę przyjęły przybyłe do USA osoby innych narodowości, to najsilniejszy kraj świata rozpadłby się na „niemieckich Amerykanów”, „irlandzkich Amerykanów” i konsekwentnie na „palestyńskich Amerykanów”. Syjonizm wydawał się więc groźny dla amerykańskiej racji stanu ${ }^{15}$. Argumenty religijne,

${ }^{15}$ Dwa akapity na podstawie Oppose Jewish Nationalism. Zionism Long Outgrow, Says Central Conference of Rabbis, „WP”, 5 VII 1918, s. 6; Peril in Zionism, Jews Tell Wilson. Committee Asks Him to Reconsider Indorsement, „WP”, 7 IX 1918, s. 7; Sees Danger in Zionism. Rabbi Philipson Explains Opposition to Jacob H. Schiffs Views, „NYT”, 14 IX 1918, s. 7; Gaster, New Judean State, „LAT”, 23 XI 1918, s. II4; Americanism vs Zionism. Many American Jews Unsympathetic to a Political Homeland in Palestine, Says Former Attorney General of New York, „NYT”, 22 XII 1918, s. 40; Rabbis Favor British Plan. New York Jewish Convention Indorses Palestine Homeland, „WP”, 26 XII 1918, s. 3; Calls Plan for Jewish Nation Absurd Dream. Semitic Scholar Says Bible Prophecies Cannot Be Taken Literally, "ChDT”, 3 II 1919, s. 13; Kahn Opposes Zionism. California Regrets that President Has Ignored It, „NYT”, 6 II 1919, s. 24; J. Ka h n, Why Most American Jews do not Favor Zionism. Their Allegiance to This Country Is the First Reason, and They Object to a Union of Church and State in Palestine or Elsewhere, „NYT”, 16 II 1919, s. 70; G.J. Kas per, New Hyphenism in Zionism, Declares Julius Kahn, Who Puts United 
jak widać, mieszały się w wypowiedziach przeciwników syjonizmu z politycznymi na każdym niemal kroku.

Spór trwał więc w najlepsze, a zwołanie kongresu Żydów mieszkajacych w USA oddalało się, choć miało do niego dojść już 12 września 1917 r. Wtedy jednak rząd Stanów Zjednoczonych zaangażował się w Wielką Wojnę i przeciwnicy syjonistów uzyskali kolejny argument, ażeby grać na zwłokę ${ }^{16}$, choć wybory delegatów już się w wielu miejscach odbyły, budzac ogromne emocje. O sporach w czasie corocznego zjazdu Zjednoczonych Synagog (United Synagogues of America), bardzo reprezentatywnej i wpływowej organizacji konserwatywnej części społeczności żydowskiej w USA, na początku lipca 1917 r. pisał „New York Times”. Gdy poddano pod głosowanie projekt akceptacji przez zjazd propozycji syjonistów wyłonienia delegata organizacji na kongres i przegłosowano go większością głosów, dr Cyrus Adler, pisarz, historyk, religioznawca, stojący na czele organizacji i jednocześnie członek American Jewish Committee, podał się do dymisji i opuścił miejsce przewodniczenia. Mimo że jej nie przyjęto, delegatem na Kongres Żydów Amerykańskich zostal prof. Israel Friedlander $z$ Jewish Theological Seminary. Głosowanie nie było jednakże jednoznaczne. Wzięło w nim udział 50 uczestników zjazdu na 80 uprawnionych. $Z$ tego 22 zagłosowało za wyborem Friedlandera, 11 było przeciwko, a reszta wstrzymała się od głosu. Za wyborem Friedlandera opowiedziało się więc trochę ponad $1 / 4$ uprawnionych do głosu członków zjazdu. Na uspokojenie nastrojów niewiele wpłynęła bardzo łagodna w swym wydźwięku deklaracja końcowa. Stwierdzano w niej poparcie dla odbudowy „kraju przodków” i wypełnienia nadziei na utworzenie siedziby narodowej Żydów w Palestynie, „która może być środkiem odnowienia religijnych ideałów judaizmu"17. Podobna do Adlera decyzję podjął Henry Morgenthau, były ambasador amerykański w Turcji, rezygnujac ze stanowiska przewodniczącego Komitetu Wykonawczego Wolnej Synagogi w Nowym Jorku. W liście do Komitetu wyja-

States First, „WP”, 16 II 1919, s. 12; Most Jews Oppose Zionism, Says Kahn. Representative Explains Views to Be Put before Peace Conference. Against Special State. Declared Question of Race Will Vanish if Civil and Religious Liberty Is Granted, "NYT", 9 III 1919, s. 9; Jews Will Honor Dr. Wise's Memory. Meeting at the Harmony Club Lays to Raise Fund for Famous School He Founded, „NYT”, 11 III 1919, s. 5; Anniversary Banquet of Hebrew Free Loan Society, „BG”, 20 III 1919, s. 10.

16 Sat Date Tuesday for American Jewish Congress, „BG”, 15 XI 1918, s. 6.

17 United Synagogues Clash over Zionism. Dr. Adler Resignes as a President when Delegate to Jewish Congress Chosen, „NYT”, 3 VII 1917, s. 7. 
śniał, że nie mógł dłużej współpracować $z$ rabinem tej kongregacji, Stephenem Wisem, jednym $z$ najbardziej znaczacych działaczy ruchu syjonistycznego w USA ${ }^{18}$.

Wśród opozycjonistów wobec syjonizmu wymienić można wiele wybitnych osobistości ze świata tak żydowskiego, jak i ogólnoamerykańskiego. Spośród najbardziej znanych osobistości wyróżnić wypada Juliusa Kahna, członka Izby Reprezentantów ze stanu Kalifornia przez 10 kadencji z rzędu, wspomnianego Henry'ego Morgenthaua, W.D. Philipsona - duchownego $z$ Cincinatti, Simona Wolfa $z$ Waszyngtonu (B'nai B'rith) czy sędziego Simona Rosendale'a $z$ Albany, byłego prokuratora generalnego w stanie Nowy Jork. Stanęli oni na czele protestu 300 Żydów, wystosowanego pod adresem prezydenta Wilsona ${ }^{19}$, gdy ten oficjalnie poparł dążenia ruchu syjonistycznego na poczattku marca 1919 r. ${ }^{20}$

Cała przytoczona argumentacja antysyjonistów wskazuje na ogromne emocje panujące wokół kwestii palestyńskiej w szeregach diaspory żydowskiej w USA. Był to kluczowy powód, przez który nie mogło dojść do skutku zwołanie Kongresu Żydów Amerykańskich przez cała I wojnę światowa. Tym niemniej życie nie stało w miejscu i 11 listopada 1918 r. w Europie zakończyły się walki. W ślad za tą informacją w prasie zaczęły się pojawiać złowróżbne wieści o złym traktowaniu Żydów na terenach Europy Środkowo-Wschodniej. Po pogromie we Lwowie (21-23 listopad 1918) wydawało się, że w życiu wyznawców judaizmu spełniały się najgorsze prognozy i trzeba było działać szybko, ażeby nie dopuścić do dalszego tego typu zajść. Sytuacja wymagała jedności działania wszystkich Żydów, którzy mogli wywrzeć jakikolwiek wpływ na polepszenie doli pobratymców na ziemiach byłych wielonarodowych imperiów rosyjskiego i habsburskiego. W listopadzie i grudniu 1918 r. los tych terenów był trudny do przewidzenia, mimo planów mocarstw odbudowania państwa polskiego. Po zajściach antyżydowskich, relacjonowanych przez prasę, powstanie Polski nie budziło wśród

18 Quit Because of Zionism. Morgenthau Explains Resignation as President of Free Synagogue, „NYT”, 7 III 1919, s. 18.

19 Protest of 300 Jews against Zionism, „BG”, 6 III 1919, s. 4; Anti-Zionists Oppose Nation in Palestine. President Wilson's Given Views to Take to the Peace Meeting, „ChDT”, 6 III 1919, s. 4.

20 Wilson Favors Jewish State. Zionist Commonwealth in Palestine Approved. Views Are Voiced at White House Conference. President Predicts Allies' Fullest Support, „LAT”, 4 III 1919, s. II8; Zionist Given Approval by President. Wilson Assures Jews Efforts for New Palestine, "ChDT”, 3 III 1919, s. 3. 
przywódców najważniejszych nurtów politycznych żydowskiej diaspory szczególnego entuzjazmu. Optymizmem nie napawały ich też rozmowy przeprowadzone przez nich na gruncie amerykańskim z Romanem Dmowskim, przywódca Komitetu Narodowego Polskiego (dalej: KNP) w październiku 1918 r. ${ }^{21}$ Oprócz działań podejmowanych na własną rękę $e^{22}$ sędzia Julian Mack, przewodniczący FAZ, i Louis Marshall, stojacy na czele AJC, wystosowali wspólny apel. Zawarli w nim obawy, że w Europie Środkowo-Wschodniej mogłoby dojść do masakr Żydów w skali przewyższajacej pogromy rosyjskie z 1905 r. W zaistniałej sytuacji zawezwali rządy państw Ententy do przeciwstawienia się takiemu scenariuszowi, szczególnie prawdopodobnemu w Polsce i Rumunii ${ }^{23}$.

Wkrótce też prasa podawała, że Komitet Administracyjny Kongresu Żydów Amerykańskich pod przewodnictwem pułkownika Harry'ego Cutlera, związanego z Federacją Amerykańskich Syjonistów, ustalić miał nową datę rozpoczęcia jego obrad. Spośród tematów za najważniejsze uchodziły dwa. Po pierwsze, chodziło o odbudowę życia żydowskiego w Palestynie, a po drugie, o zagwarantowanie równych praw Żydom w Europie. W obu przypadkach do spotkania przynaglała zbliżająca się Konferencja Pokojowa w Paryżu. Żydzi amerykańscy chcieli wysłać na nia swoją delegację, ażeby przedstawiła ich punkt widzenia w obu kwestiach ${ }^{24}$. W szeregach Żydów amerykańskich coraz częściej zdawał się zwyciężać pogląd, że kontrowersja syjonizm-antysyjonizm nie powinna ich dzielić. Z kontaktów osobistych wiedzieli, że do Paryża wybierały się delegacje $z$ wielu krajów i oddzielne występowanie siedmiu czy ośmiu takich reprezentacji żydowskich nie miało szans niczego

${ }^{21}$ A. Kapiszewski, Stosunki polsko-żydowskie $w$ Stanach Zjednoczonych Ameryki, [w:] Polonia amerykańska. Przeszłość i współczesność, red. H. Kubiak, E. Kusielewicz, T. Gromada, Wrocław 1988, s. 621-622; J. Le rs ki, Dmowski, Paderewski and American Jews. A Documentary Compilation, „Polin” 1986, s. 99-114. Por. też relację Dmowskiego - R. D mowski, Polityka polska i odbudowanie pañstwa, t. II, Warszawa 1989, s. 93-94.

${ }^{22}$ G.D. Best, op. cit., s. 216-218; Protect Jews. American Jewish Committee Urges the Allies to Guard Rights of Their Countrymen, „ChDT”, 11 XI 1918, s. 11.

23 Jews Fear Vast Pogroms in Eastern Europe, "ChDT”, 14 XI 1918, s. 2.

${ }^{24}$ Jewish Congress to Meet. Administrative Committee to Fix Date Tomorrow for Session, „NYT”, 25 XI 1918, s. 15; Jewish Congress Meeting in Philadelphia, Dec 15, „BG”, 27 XI 1918, s. 20; Jewish Congress to Meet. Will Assemble with 400 Delegates in Philadelphia on Sunday, „NYT”, 11 XII 1918, s. 17; Jews Ask Voice at Peace Table. Congress in Philadelphia to Take Up Palestine and Other Questions, „WP”, 14 XII 1918, s. 9. 
wskórać. W oficjalnych wypowiedziach liderów, jak choćby Jacoba Schiffa, pojawiać się zaczęły coraz ostrzejsze sformułowania w stylu: Palestyna nie jest konieczna dla Żydów amerykańskich lub brytyjskich, czy francuskich, ale dla „zaszczutych Żydów w Polsce, Galicji i Rumunii”. Bankier zdawał sobie sprawę, że wywalczenie równych praw politycznych, religijnych i obywatelskich było możliwe na Konferencji Pokojowej, lecz nie oznaczało to jeszcze zdobycia sympatii ze strony ludności narodów większościowych. Dlatego też uznawał kwestię palestyńska jako równie ważną ${ }^{25}$.

Przeciwnikom syjonizmu nie pozostawało nic innego jak podjąć współpracę z Federacją Amerykańskich Syjonistów, aby dać przykład Żydom $z$ państw europejskich, głównie $z$ Francji i Wielkiej Brytanii, że możliwe, a nawet konieczne, było jednoczenie sił. Zgodzili się więc na kongres, który odbyć się miał w Filadelfii. Wywalczyli przy okazji dwa ustępstwa na syjonistach. Przede wszystkim mieli oni nie podnosić na Konferencji Pokojowej postulatu uznania Żydów za odrębny naród w skali świata. Należy w tym miejscu przypomnieć, że Światowa Organizacja Syjonistyczna ogłosiła swój powojenny program na konferencji w Kopenhadze 28 października 1918 r. Składał się z czterech punktów: uznanie Palestyny w jej historycznych granicach za siedzibę narodową Żydów, przyznanie osobom tej narodowości równych praw we wszystkich krajach ich osiedlenia, a także zagwarantowanie im autonomii kulturalno-narodowej, wreszcie: uznanie Żydów za oddzielny naród i dopuszczenie ich do członkostwa w Lidze Narodów ${ }^{26}$. Drugim ustępstwem syjonistów była obietnica, że kongres filadelfijski będzie inicjatywą jednorazowa, po której nie nastapi żadna kontynuacja instytucjonalna wspólnej reprezentacji Żydów amerykańskich ${ }^{27}$.

Po osiagniętych ustaleniach nie pozostawało już nic innego niż rozpocząć Kongres. Zgodnie $z$ żydowskimi przepisami religijnymi w pierwszy dzień po szabacie, w niedzielę 15 grudnia 1918 r. rozpoczęło się w Filadelfii długo oczekiwane spotkanie. Pułkownik Harry Cutler, jako szef Komitetu Administracyjnego, oficjalnie rozpoczął Kongres. Główny rabin filadelfijski B.L. Levinthal poprowadził modlitwę o powodzenie obrad. W otwierajacej mowie Cutler

${ }^{25}$ Jews Will Honor Dr. Wise's Memory. Meeting at the Harmony Club Lays to Raise Fund for Famous School He Founded, „NYT”, 11 III 1919, s. 5.

${ }^{26}$ J. Parkes, op. cit., s. 111; B. Bouffałł, Ochrona mniejszości w prawie narodów, Warszawa 1928, s. 156.

27 M. Epstein, op. cit., s. 62-63. 
przypominał o prześladowaniach dotykających „naród żydowski” od tysięcy lat i wyrażał nadzieję, że po Wielkiej Wojnie zbiorowość ta będzie mogła stanąc na własnych nogach. To sformułowanie zostało odebrane jako aluzja do Palestyny i nagrodzone entuzjastycznymi brawami przez przeważających na zgromadzeniu syjonistów. Cutler skonkludował swoje wystąpienie stwierdzeniem, że Żydom na całym świecie należą się równe prawa obywatelskie, religijne i polityczne ze względu na ofiary, jakie ponieśli w czasie wojny. Wątek ten przewijał się zresztą w wielu przemówieniach wygłaszanych w trakcie Kongresu. W pierwszym dniu powtarzali je prof. David Abram $z$ Uniwersytetu w Pennsylwanii i Nathan Straus jako honorowy przewodniczacy Kongresu, znany ze swej nowojorskiej wytwórni ozdobnych zastaw stołowych, która dała mu fortunę.

Pierwszy dzień Kongresu miał jeszcze jeden istotny aspekt, czyli wybory władz. Stanowisko przewodniczacego przypadło Julianowi Mackowi (FAZ), a wiceprzewodniczaccego - Louisowi Marshallowi (AJC). W mowie inaugurującej po przyjęciu nowej funkcji Mack pojednawczo zadeklarował, że najważniejsze w powojennej rzeczywistości było zagwarantowanie praw i dobrobytu dla Żydów w Polsce i Rumunii. Należało zdefiniować metody działania pozwalające na współpracę $z$ Żydami $z$ innych państw. Po wypracowaniu wspólnej płaszczyzny programowej chodziło również o wpłynięcie przez Konferencję Pokojową na wszystkie istniejace lub mające powstać rządy, aby nie prześladowały Żydów $z$ jakichkolwiek powodów. Kwestię palestyńska, choć jeszcze nie w formie własnego państwa, uznał już za rozwiązana przez zwycięskie mocarstwa. Było to niewątpliwie stwierdzenie przesadzone i jednocześnie podkreślało wolę współpracy z niesyjonistycznymi środowiskami reprezentowanymi na Kongresie. Należy jednakże zauważyć, że w czasie obrad, i to już pierwszego dnia, nie brakowało akcentów mogących podnieść temperaturę sporu politycznego między delegatami. Pojawiły się m.in. sformułowania, że przekształcenie Konferencji Pokojowej w Lige Narodów doprowadzi do odtworzenia „narodowości żydowskiej”. Przez cały dzień wielokrotnie wyrażano owacje na część prezydenta Wilsona, po którym spodziewano się pomocy w realizacji własnych nadziei ${ }^{28}$.

${ }^{28}$ Dwa akapity na podstawie Jews Plan Unity in First Congress. Nathan Straus Addressed Philadelphia Meeting Held for Defining of Aims. Makes Plea for Liberty. Wilson's Name Stirs Delegates to Prolonged Cheering. Judge J.W. Mack President, 
Prawdziwa praca rozpoczęła się jednak dopiero następnego dnia. Nie chodziło już bowiem o słowne przepychanki, lecz o konkretne rezolucje, które należało przyjąć jako program dalszego działania. Najpierw zajęto się kwestia palestyńska i po goracych obradach przyjęto deklarację zatytułowana „Jewish Commonwealth in Palestine". Zaprezentował ja prof. Harry Friedenwald $z$ Baltimore. Głoszono w niej konieczność odbudowania ojczyzny żydowskiej w Palestynie. Wyrażono poparcie dla brytyjskiego powiernictwa nad tym terytorium $z$ ramienia oczekiwanej Ligi Narodów. Delegacji Kongresu, która miała wyjechać do Paryża, zlecono współpracę ze Światową Organizacją Syjonistyczna w celu wpłynięcia na Konferencję Pokojową, ażeby uznała „aspiracje historyczne Żydów” w kwestii Palestyny w myśl deklaracji lorda Balfoura. Liczacc na pomoc Brytyjczyków na miejscu, ale również pozostałych mocarstw zwycięskich, chciano stworzyć „odpowiednie warunki polityczne, administracyjne i gospodarcze" dla osiedlenia Żydów. Deklarowano jednocześnie zamiar przyznania równości praw cywilnych i religijnych dla innych „mieszkających tam ludów nieżydowskich". Syjoniści amerykańscy przedstawiali swoje plany rozwoju gospodarczego Palestyny, a wielu bogatych uczestników Kongresu deklarowało konkretne sumy na wsparcie ich działań. Rezolucję przyjęto niemal jednogłośnie (padł jeden głos sprzeciwu) w bardzo podniosłej atmosferze i $z$ dużym entuzjazmem zebranych. Relacjonujacy obrady Kongresu reporter „New York Timesa” odnotował odśpiewanie hymnu Hatikvah przy powiewających flagach, zarówno amerykańskich, jak i syjonistycznych ${ }^{29}$.

Drugim ważnym punktem obrad Kongresu był wybór delegatów, którzy mieli wypłynąć do Europy. Do wyznaczonych im zadań należał szybki wyjazd $z$ USA i nawiązanie współpracy z Żydami $z$ innych krajów w celu osiagnięcia celów zarysowanych na Kongresie. Delegatów zobowiazano do złożenia raportu $z$ wykonania

„NYT”, 16 XII 1918, s. 24; Jewish Congress Voices Its Hopes, „BG”, 16 XII 1918, s. 6; American Jews Ask Full Rights in All Nations. Judge Mack, Chicago, Named President of Congress, „LAT”, 16 XII 1918, s. I5.

${ }^{29}$ Indorse Jewish Palestine State. Congress at Philadelphia Favors British Protectorate. Peace Conference Delegates Chosen. Equal Rights in All Nations Asked, „BG”, 18 XII 1918, s. 1-2; Adopts Palestine as Jewish Homeland. Philadelphia Congress Votes to Establish Commonwealth under Britain's Trustship. Delegates Going to Paris. Elkus, Straus and Morgenthau Are Mentioned as Envoys to the Paris Conference, „NYT”, 18 XII 1918, s. 24; Jews Look to Britain. Philadelphia Congress Wants London Trustee in Palestine. For Non-Hebrew Rights, „WP”, 18 XII 1918, s. 8. 
misji najpóźniej rok po podpisaniu traktatu pokojowego. Była to więc pośrednia zapowiedź, że prace Kongresu nie będa jednak jednorazowe. Inna furtka pozwalajaca na kontynuowanie działań Kongresu Żydów Amerykańskich była możliwość wystąpienia o nowe instrukcje w razie zmiany warunków działania delegacji. Najwięcej emocji wywołały $z$ oczywistych względów wybory delegatów. Początkowo zgodzono się na siedem osób, ale ostatecznie wybrano o dwie więcej. Dyskutowano, jak najlepiej dobrać skład osobowy. Pojawiła się koncepcja postawienia na doświadczonych dyplomatów, jak Henry Morgenthau, Abraham Elkus (również były ambasador USA w Turcji) czy Oscar Straus, którzy wiedzieli, jak poruszać się w świecie wielkiej polityki. Choć autor tekstu prasowego nie napisał tego, można się domyślić, że taką koncepcję zgłaszali przeciwnicy syjonizmu. Konkurencyjna była wizja wysłania jak najbardziej reprezentatywnej dla całego Kongresu delegacji. Wtedy wszystkie ugrupowania miałyby liczbę delegatów proporcjonalna do ich siły liczebnej na Kongresie. Syjonistyczna propozycja znalazła, jak można się spodziewać, poparcie większości zebranych i została zrealizowana ${ }^{30}$.

W skład delegacji Kongresu Żydów Amerykańskich weszli ostatecznie: Julian Mack z Chicago jako przewodniczący, rabin Stephen Wise $z$ Nowego Jorku - reprezentujacy FAZ (w tym czasie był już w Europie i wybrany został zaocznie), rabin B.L. Levinthal z Filadelfii z ramienia Mizrachi i rabinów ortodoksyjnych, płk Harry Cutler $z$ Providence jako syjonista, Jacob de Haas - kolejny przedstawiciel nowojorski - sekretarz generalny FAZ, Louis Marshall $z$ Nowego Jorku w imieniu AJC, dr Joseph Barondess - spokrewniony $z$ Louisem Brandeisem - radykalny nowojorski związkowiec producentów garderoby, Morris Winchefsky - pisarz nowojorski reprezentujący socjalistów-rewolucjonistów i Nachman Syrkin z Poalej Syjon. Do delegacji dokooptowano dodatkowo Bernarda G. Richardsa, aby pełnił obowiązki sekretarza. Po składzie osobowym widać zdecydowana dominację syjonistów oraz reprezentantów Żydów nowojorskich ${ }^{31}$.

${ }^{30}$ Adopts Palestine as Jewish Homeland. Philadelphia Congress Votes to Establish Commonwealth under Britain's Trustship. Delegates Going to Paris. Elkus Straus and Morgenthau Are Mentioned as Envoys to the Paris Conference, "NYT", 18 XII 1918, s. 24; Jews Look to Britain. Philadelphia Congress Wants London Trustee in Palestine. For Non-Hebrew Rights, „WP”, 18 XII 1918, s. 8.

${ }^{31}$ Jews Propose Equal Rights. Hebrew Congress Drafts Bill for Peace Discussion. Would Have Principles Incorporated in New States. Racial and Religious Freedom 
Kolejnym tematem Kongresu była kwestia postulowanych równych praw cywilnych, religijnych i politycznych dla Żydów w krajach Europy Środkowo-Wschodniej. Referujacy sprawę na obradach plenarnych Louis Marshall ograniczył terytorialnie grono państw, które byłyby objęte „Kartą Praw”, jak nazwano listę postulatów żydowskich. Pewnego rodzaju pomostem, służącym do przejścia do tego tematu, była dyskusja o Rumunii, dyskryminujaccej prawnie Żydów w okresie poprzedzającym wojnę światową ${ }^{32}$. Marshall, przemawiając trzeciego dnia Kongresu, postulował, ażeby uzależnić uznanie dyplomatyczne państw Europy Środkowo-Wschodniej od przyjęcia poniższych zobowiązań:

1) wszystkim mieszkającym na terenie danego państwa przed 1 sierpnia 1914 r. osobom i ich rodzinom należy się obywatelstwo, jeśli uciekli przed zawieruchą wojenna lub zostali przesiedleni i w ciągu 10 lat zdecydowaliby się powrócić (wyjątkiem jest formalne zadeklarowanie woli pozostania w innym kraju) - to echa przedwojennej polityki Rumunii;

2) przez 10 lat od wejścia w życie tych przepisów nie można by wprowadzać praw ograniczajacych wcześniejszym mieszkańcom danego terytorium aspirowania do obywatelstwa danego państwa;

3) gwarancja równego traktowania bez żadnej dyskryminacji i zagwarantowania równych praw cywilnych, religijnych, politycznych i narodowych bez względu na rasę, narodowość czy wyznanie - realizacja typowo liberalnej koncepcji równości negatywnej, czyli takich samych praw wszystkich obywateli w kraju;

4) prawne zapewnienie reprezentacji mniejszości w ciałach przedstawicielskich narodów większościowych;

5) członkowie wszystkich narodowości i wyznań (widać kompromisowe podejście do sporu amerykańskich syjonistów $\mathrm{i}$ antysyjonistów) $\mathrm{w}$ danym państwie mieliby autonomiczny zarząd nad swymi instytucjami religijnymi, edukacyjnymi,

Urged on All Nations, „LAT”, 19 XII 1918, s. II7; To Present Aims of Jews at Versailles. Committee of Nine Named at Philadelphia. Commission Named to Look into Situation in Poland, „BG”, 19 XII 1918, s. 3.

${ }^{32}$ Indorse Jewish Palestine State. Congress at Philadelphia Favors British Protectorate. Peace Conference Delegates Chosen. Equal Rights in All Nations Asked, „BG”, 18 XII 1918, s. 2. 
charytatywnymi i wszystkimi innymi - to główny postulat koncepcji autonomii kulturalno-narodowej, wydzielajaccej mniejszości jako odrębne całości, posiadające osobowość prawną w relacjach $z$ władzami kraju;

6) odrzucenie wszelkich prawnych ograniczeń w kwestii wolnego używania własnego języka;

7) osobom obchodzacym szabat zagwarantowano możliwość załatwiania swoich spraw świeckich w niedziele i nie nakłaniano do czynności urzędowych w soboty i inne dni świąteczne - w zamyśle Marshalla chodziło o wybory lub rozprawy sacowe ${ }^{33}$.

Zaprezentowane postulaty lidera AJC zostały zaakceptowane przez Kongres, co było poprzedzone negocjacjami $z$ syjonistami. Porównanie ich $z$ wcześniejszymi żądaniami Marshalla, zgłaszanymi choćby w trakcie rozmowy $z$ Romanem Dmowskim 6 października 1918 r., pokazuje, że dodano zaledwie dwa punkty (drugi o prawie opcji i czwarty o proporcjonalnej reprezentacji mniejszości). Natomiast zaostrzeniu uległa retoryka. Kwestionowano bowiem uznanie dyplomatyczne krajów takich jak chociażby Polska ${ }^{34}$. Może to oznaczać, że dążenia lidera Amerykańskiego Komitetu Żydowskiego były już dobrze przez niego przemyślane wcześniej i to właśnie on nadawał ton obradom Kongresu w tym punkcie. Niewatpliwie nie jest prawda, że Marshall, a wraz z nim cały Kongres Żydów Amerykańskich kierowali się w swoich żądaniach liberalizmem i koncentrowali się jedynie na zabezpieczeniu losu jednostek odrębnych od narodu większościowego ze względów religijnych, językowych lub rasowych. Niewątpliwie delegacja Kongresu wyjeżdżająca do Paryża miała w swym programie walkę o prawa zbiorowe Żydów w Europie Środkowo-Wschodniej, czyli o tzw. równość pozytywną lub - inaczej mówiąc - wspieranie odrębności ${ }^{35}$.

${ }^{33}$ Jews Propose Equal Rights. Hebrew Congress Drafts Bill for Peace Discussion. Would Have Principles Incorporated in New States. Racial and Religious Freedom Urged on All Nations, „LAT”, 19 XII 1918, s. II7. Por. też D. J e zi o r ny, Akcja amerykańskich organizacji żydowskich na rzecz międzynarodowej ochrony praw mniejszości (1918-1919), „Acta Universitatis Lodziensis”, Folia Historica 59, 1997, s. 9-10.

${ }^{34}$ Por. J. Lerski, op. cit., s. 102.

35 Por. błędna analizę L. Riga i J. Kennedy, Tolerant Majorities, Loyal Minorities and "Ethnic Reversals": Constructing Minority Rights at Versailles 1919, „Nations and Nationalism” 2009, vol. XV, No. 3, s. 462-470, 477-478. 
Trzeciorzędne znaczenie miały już pozostałe kwestie poruszane na Kongresie: próba podjęcia tematu uznania Żydów jako narodowości w skali świata, przyjęcie listu Tomaša G. Masaryka o powstrzymaniu deportacji galicyjskich Żydów z Pragi, protest wobec aresztowania czterech lwowskich syjonistów w Przemyślu, przyjęcie życzeń od kongresu Ukraińców mieszkających w USA odbywającego się w tym samym czasie, manifestacja na zakończenie Kongresu do miejsca, w którym uchwalono Deklarację Niepodległości Stanów Zjednoczonych ${ }^{36}$. Najistotniejsza $z$ punktu widzenia Polski była akceptacja Louisa Marshalla, a za nim całego Kongresu, wysłania do Polski mieszanej komisji, która miałaby zbadać rzeczywiste położenie Żydów na ziemiach podlegających suwerenności Warszawy. Zgłosił ja Jan Smulski, kierownik Wydziału Narodowego w Chicago, znany działacz polonijny w USA. Kongres Żydów Amerykańskich, nie wierząc tłumaczeniom Polaków kwestionujących pogłoski o pogromach, zgodził się wysłać swoich przedstawicieli ${ }^{37}$, ale ostatecznie inicjatywa przepadła.

Cały Kongres Żydów Amerykańskich zakończył się 18 grudnia 1918 r. w atmosferze wielkiego entuzjazmu. Przyjęto na nim dwa istotne dla dalszego biegu wydarzeń dokumenty dotyczące Palestyny i walki o prawa mniejszości żydowskich w Europie Środkowo-Wschodniej. Wysłana do Paryża na Konferencję Pokojowa delegacja Kongresu miała silną legitymację do prezentowania własnych żądań. Była delegowana przez całą, ponad trzymilionową społeczność żydowską w USA. Po przybyciu do stolicy Francji przeżyła jednakże dwa poważne rozczarowania. Po pierwsze, nie była traktowana jako oficjalny uczestnik obrad, gdyż taki status zarezerwowany był jedynie dla członków zwycięskiej koalicji ${ }^{38}$. Pozosta-

${ }^{36}$ Indorse Jewish Palestine State. Congress at Philadelphia Favors British Protectorate. Peace Conference Delegates Chosen. Equal Rights in All Nations Asked, „BG”, 18 XII 1918, s. 2; To Present Aims of Jews at Versailles. Committee of Nine Named at Philadelphia. Commission Named to Look into Situation in Poland, "BG”, 19 XII 1918, s. 3.

37 Jews Propose Equal Rights. Hebrew Congress Drafts Bill for Peace Discussion. Would Have Principles Incorporated in New States. Racial and Religious Freedom Urged on All Nations, „LAT”, 19 XII 1918, s. II7. Por. Sprawozdanie dla KNP, Filadelfia 15 XII 1918, Archiwum Akt Nowych w Warszawie, Komitet Narodowy Polski, teczka 159, k. 117.

38 Papers Relating to the Foreign Relations of the United States. Paris Peace Conference, vol. III, Washington 1943, s. 535-537, 540-541 (posiedzenia Rady Dziesięciu z 13 I 1919); M. Hankey, The Supreme Control at the Paris Peace Conference 1919. A Commentary, London 1963, s. 79-80. 
wało im więc używanie jedynie nieformalnych wpływów na obrady Konferencji Pokojowej. Po drugie, całkowitym fiaskiem zakończyła się próba utworzenia jednolitego ciała reprezentującego wszystkich Żydów przybyłych $z$ różnych krajów świata. Mimo prób oparcia programu na wypracowanym w Filadelfii kompromisie organizacje niechętne syjonizmowi z Francji (Alliance Isräelite Universelle) i Wielkiej Brytanii (Joint Foreign Committee) odmówiły współpracy, a nawet usiłowały przeciągnąc Louisa Marshalla na swoją stronę. W efekcie Żydzi amerykańscy zawarli porozumienie $z$ delegacjami przybywajacymi $z$ Europy Środkowo-Wschodniej, zdominowanymi przez syjonistów. Natomiast antysyjonistycznie nastawieni Żydzi francuscy i brytyjscy działali całkowicie oddzielnie, choć ich programy zagwarantowania praw pobratymców w państwach nowych niewiele się różniły od propozycji Marshalla ${ }^{39}$.

W trakcie zmagań dyplomatycznych na Konferencji Pokojowej podjęto dwie istotne decyzje dotyczące Żydów. Po pierwsze, Palestyna stała się mandatem brytyjskim typu A. Londyn sprawował go formalnie $z$ ramienia Ligi Narodów od lipca 1922 r., ale już od czasu zdobycia Jerozolimy w grudniu 1917 r. panował nad tym terytorium. Najpierw był to zarzad wojskowy, a następnie od 1 lipca 1920 r. cywilny z Wysokim Komisarzem na czele. Mieli więc możliwość, a od 1922 r. zobowiązanie wprowadzania w życie tego, co zadeklarował Balfour 2 listopada 1917 r. ${ }^{40}$ Można więc śmiało uznać, że w kwestii głównego postulatu syjonistów Żydzi uzyskali dokładnie to, czego wówczas pragnęli. Późniejszych rozczarowań co do polityki brytyjskiej w latach trzydziestych nie mogli przewidzieć. Po drugie, państwa Europy Środkowo-Wschodniej zmuszone zostały do podpisania tzw. zobowiązań mniejszościowych. Co do treści pokrywały się one $z$ większościa postulatów Kongresu Żydów Amerykańskich. Różnica było pominięcie wszelkich treści mogących sugerować cokolwiek innego niż ochronę jednostek należących do mniejszości rasowych, religijnych lub językowych (koncepcja równości negatywnej). Nie udało się więc wywalczyć autonomii kulturalno-narodowej, co niewatpliwie stanowiło cios wymierzony w jeden $z$ podstawowych postulatów syjonistów. Górę wzięła taka interpretacja wilsonowskiej zasady samostanowienia narodów zakładającej, że w jednym państwie mógł zamieszkiwać tylko jeden naród. Stąd w treści tzw. traktatów mniejszościowych

${ }^{39}$ Szerzej D. Jeziorny, Londyn..., s. 56-61, 106-108.

40 A. Patek, Żydzi $w$ drodze do Palestyny 1934-1944, Kraków 2009, s. 35-38. 
nie znalazło się wyrażenie o mniejszościach narodowych. Głównym promotorem takiego sformułowania zobowiązań państw Europy Środkowo-Wschodniej była dyplomacja brytyjska, wbrew stanowisku Amerykanów, pozostających w Paryżu w kontakcie $z$ wysłannikami Kongresu Żydów Amerykańskich ${ }^{41}$.

Mimo dwóch ważnych sukcesów osiagniętych w Paryżu przez delegatów żydowskich zza Oceanu Atlantyckiego idea Kongresu Żydów Amerykańskich nie odniosła spodziewanego sukcesu. Zaraz po złożeniu sprawozdania $z$ działań w Paryżu przedstawiciele ugrupowań niesyjonistycznych wycofali się z organizacji. Chodziło głównie o Amerykański Komitet Żydowski oraz partie socjalistyczne. Kongres Żydów Amerykańskich kontynuował działalność jako organizacja o profilu syjonistycznym, której przewodniczył przez kolejne niemal 30 lat rabin Stephen Wise. W takiej też formie funkcjonuje do dziś, choć po roku 2010 zdecydowanie ograniczył swoją aktywność $z$ powodu braku pieniędzy - padł ofiara machinacji finansowych Bernarda Mudoffa ${ }^{42}$.

Kongres filadelfijski był więc jednorazowym wydarzeniem jako spotkanie, na którym reprezentowane były wszystkie nurty polityczne Żydów amerykańskich. Budził ogromne nadzieje i entuzjazm u zwykłych ludzi pochodzenia żydowskiego, stanowiąc wręcz symbol jedności w obliczu epokowych zmian w światowej polityce po zakończeniu I wojny światowej. Był efektem kompromisu konkurujacych ze sobą organizacji politycznych, pozwalajacego wysłać do ówczesnej stolicy świata jedną silna reprezentację. W świecie żydowskim cieszyła się ona niewątpliwym prestiżem - na tyle dużym, że w Komitecie Delegacji Żydowskich przy Konferencji Pokojowej w Paryżu funkcje przewodniczacego i wiceprzewodniczącego powierzono właśnie delegatom z USA, Julianowi Mackowi i Louisowi Marshallowi. W Paryżu zdołali oni zrealizować zdecydowana większość zadań, które przed nimi postawiono w kwestii palestyńskiej i ochrony praw mniejszości w Europie Środkowo-Wschodniej. W tym sensie kongres stanowił jedna $z$ „najdonioślejszych epok w życiu Żydów".

${ }^{41}$ Więcej na ten temat por. D. J eziorny, Londyn..., s. 127-154.

${ }^{42}$ N. Glazer, op. cit., s 27; https://en.wikipedia.org/wiki/American_Jewish_ Congress. 


\section{Bibliografia}

\section{Ż́ódeA ARChIWALNe}

Archiwum Akt Nowych w Warszawie

Komitet Narodowy Polski, teczka 159.

\section{ŹRódea DRUKOWANE}

Papers Relating to the Foreign Relations of the United States. Paris Peace Conference, vol. III, Washington 1943.

\section{Prace polityków}

Dmowski R., Polityka polska i odbudowanie państwa, t. II, Warszawa 1989.

Hankey M., The Supreme Control at the Paris Peace Conference 1919. A Commentary, London 1963.

\section{Prasa}

„Boston Globe” 1918-1919.

"Chicago Daily Tribune” 1918-1919.

„Los Angeles Times” 1918-1919.

„New York Times” 1918-1919.

„Washington Post” 1918-1919.

\section{OpRacowania}

Best G.D., To Free a People. American Jewish Leaders and the Jewish Problem in Eastern Europe 1890-1914, Westpork 1982.

Bouffałł B., Ochrona mniejszości w prawie narodów, Warszawa 1928.

Cohen G., Jews in the Making of America, Boston 1924.

Daniels J., The Wilson Era. Years of War and After, New York 1946.

Epstein M., Jewish Labour in USA. An Industrial, Political and Cultural History of Jewish Labour Movement. 1914-1952, vol. II, New York 1969.

Glazer N., The Jews, [w:] Ethnic Leadership in America, ed. J. Higham, BaltimoreLondon 1979, s. 19-35.

Goren A.A., New York Jews and the Quest for Community. The Kehillah Experiment 1908-1922, New York-London 1970.

Hertzberg A., Hirt-Manheimer A., Żydzi. Istota i charakter narodu, Warszawa 2001.

Jaworski W., Syjoniści wobec rzadu polskiego w okresie międzywojennym, Sosnowiec 2002.

Jeziorny D., Akcja amerykańskich organizacji żydowskich na rzecz międzynarodowej ochrony praw mniejszości (1918-1919), „Acta Universitatis Lodziensis”, Folia Historica 59, 1997, s. 5-19. 
Jeziorny D., Londyn wobec ochrony mniejszości żydowskich w Europie Środkowo-Wschodniej (1918-1919), Łódź 2016.

Kapiszewski A., Stosunki polsko-żydowskie w Stanach Zjednoczonych Ameryki, [w:] Polonia amerykańska. Przeszłość i współczesność, red. H. Kubiak, E. Kusielewicz, T. Gromada, Wrocław 1988, s. 609-672.

Lerski J., Dmowski, Paderewski and American Jews. A Documentary Compilation, „Polin” 1986, s. 95-116.

Loeffler J., Nationalism without a Nation? On the Invisibility of American Jewish Politics, „The Jewish Quarterly Review” 2015, vol. CV, No. 3, s. 367-398.

Mason A.T., Brandeis. A Free Man's Life, New York 1946.

Parkes J., The Emergence of the Jewish Problem. 1879-1939, London-New YorkToronto 1946.

Pastusiak L., Prezydenci, wyd. 2, t. II, Warszawa 1989.

Patek A., Żydzi w drodze do Palestyny 1934-1944, Kraków 2009.

Pogroms: Anti-Jewish Violence in Modern Russian History, eds J.D. Klier, S. Lambroza, Cambridge 1992.

Poliakov L., Historia antysemityzmu, t. II, Kraków 2008.

Polonsky A., Dzieje Żydów w Polsce i Rosji, Warszawa 2014.

Racial and Cultural Minorities. Analysis of Prejudice and Discrimination, rev. eds G.E. Simpson, J.M. Yinger, New York 1958.

Riga L., Kennedy J., Tolerant Majorities, Loyal Minorities and „Ethnic Reversals”: Constructing Minority Rights at Versailles 1919, „Nations and Nationalism” 2009, vol. XV, No. 3, s. 461-482.

Sklare M., The Jewish Community in America, New York 1974.

Unterman A., Żydzi. Wiara i życie, Łódź 1989.

\section{Netografia}

https://en.wikipedia.org/wiki/American_Jewish_Congress. https://pl.wikipedia.org/wiki/B'nai_B'rith.

DARIUSZ JEZIORNY

\section{"The most momentous epochs in Jewish life" American Jewish Congress in Philadelphia (December 15-18, 1918)}

\footnotetext{
$\mathrm{T}$
} he Congress of American Jews began its activities as an organization established to represent all Jews living in the United States during the Congress in Philadelphia. On December 15-18, 1918, a meeting of 400 delegates representing all Jewish political parties and social groups in the USA took place. It aroused great hopes because new opportunities were opening up for the Jews 
to resolve the Palestinian question, the main Zionist project, and to guarantee equal rights for Jewish minorities in East-Central Europe. The article answers questions about how the Congress of American Jews was convened. How did the main political groups of Jews in the USA respond to it? What was the subject of the debate? What decisions were made? And then how were they implemented and what was the future of the initiative launched in Philadelphia? Answers to these questions will allow us to draw a conclusion as to the importance of the December congress in the history of Jews in the USA and whether it fulfilled its tasks.

Keywords: Jews in the USA, American Jewish Congress, Palestinian question, Zionism, minority rights. 